\title{
TINGKAT PENGETAHUAN PETANI TENTANG SINAR UV TERHADAP KESEHATAN MATA
}

\author{
Jaja Muhamad Jabar ${ }^{1)}$, Silvy Nursafitri ${ }^{2}$ \\ ${ }^{1,2)}$ Program Studi Diploma Tiga Refraksi Optisi STIKes Dharma Husada Bandung \\ jabbar_muhammad20@yahoo.co.id
}

\begin{abstract}
ABSTRAK
Sinar matahari bersifat polikromatik, terdiri dari berbagai gelombang elektromagnetik seperti sinar UV. Untuk beberapa orang yang memiliki aktivitas di luar ruangan dalam kehidupan sehari-hari mereka, seperti petani, mereka akan menerima emisi sinar matahari lebih banyak daripada orang yang memiliki aktivitas di dalam ruangan. Hal itu menyebabkan mereka lebih rentan mendapatkan efek sinar UV, seperti kerusakan pada kelopak mata, kornea, lensa, dan retina. Tujuan dari penelitian ini adalah untuk mengetahui pengetahuan petani terkait dengan sumber dan bahaya sinar UV, serta pelindung mata dari sinar UV. Penelitian ini dilakukan di Subang. Metode yang digunakan dalam penelitian ini adalah deskriptif kuantitatif, dimana data dari sampel penelitian dianalisis sesuai dengan metode statistik yang digunakan. Sampel penelitian ini adalah 78 petani, yang diberi kuesioner terdiri dari 15 pertanyaan terkait sinar UV. Hasil dari penelitian ini adalah bahwa tingkat pengetahuan petani terkait dengan sumber sinar UV $(77,4 \%)$, bahaya sinar UV $(49,2 \%)$, dan pelindung mata dari sinar UV $(70,8 \%)$. Secara umum, tingkat pengetahuan petani terkait kesehatan mata cukup baik $(65,5 \%)$.
\end{abstract}

Kata Kunci: Sinar UV, tingkat pengetahuan, petani

\begin{abstract}
The sunlight is polychromatic, consists of various electromagnetic wave such as UV light. For some people who has outdoor activities in their daily life, like the farmers, they will receive the sunlight emission more than people who has indoor activities. It causes they are be more vulnerable to get UV light effect, such as damage on eyelid, cornea, lens, and retina. The purpose of this research is to know the farmers' knowledge related to the source and danger of UV light, also eye protector from UV light. This research is done in Subang. The method that used in this research is descriptive quantitative, which the data from research sample is analyzed corresponding to statistic method that being used. The sample of this research is 78 farmers, who were given a questionnaire consists of 15 questions related to UV light. The result of this research is that the level of farmers' knowledge related to the source of UV light (77,4\%), danger of UV light (49,2\%), and eye protector from UV light $(70,8 \%)$. In general, the level of farmers' knowledge related to the eye health is good enough $(65,5 \%)$.
\end{abstract}

Key Word : UV light, knowledge level, farmer

\section{PENDAHULUAN}

Secara geografis Indonesia merupakan negara yang terletak di daerah tropis dengan paparan sinar matahari sepanjang musim. Disamping itu salah satu jenis mata pencaharian dari masyarakat Indonesia sendiri yaitu sebagai petani yang beraktivitas diluar ruangan sehingga mendapatkan paparan sinar matahari secara langsung dan jika menerima pacaran sinar matahari dalam intensitas berlebih hal ini sangat rentan terhadap kesehatan mata. Sinar matahari merupakan sinar polikromatik yang terdiri dari berbagai macam gelombang (sinar) elektromagnetik salah satunya sinar UV. Sinar UV merupakan sinar yang mempuyai panjang gelombang sampai ke permukaan bumi yang terdiri dari sinar UV-A, sinar UV-B dan sinar UV-C. Jenis sinar UV-A yang memiliki rentang panjang gelombang 315-400 nm, semuanya diemisikan 
ke permukaan bumi, sinar UV-B dengan rentang panjang gelombang 315-280 nm hanya sebagian yang diemsikan ke permukaan bumi, sedangkan sinar UV-C yang memiliki rentang panjang gelombang 280-180 nm tidak diemisikan ke permukaan bumi karena di serap lapisan ozon yang ada di atmosfer bumi. Tetapi jenis sinar UV-C tidak menutup kemungkinan emisinya sampai ke permukaan bumi jika lapisan ozon rusak. Akhir-akhir ini kita dihadapkan dengan fenomena global warning yang dapat menyebabkan lapisan ozon meipis. Fenomena global warming yang berdampak pada penipisan lapisan ozon dibumi di akibatkan polusi kimia chorofluoro carbon (CFC) yang berasal dari mesin pendingin (AC,kulkas) dan industri sehingga mengakibatkan intensitasnya semakin tinggi, maka meyebabkan radiasi UV-C sampai kepermukaan bumi dan berakibat buruk terhadap mahluk hidup. Sinar UV-C adalah sinar dengan energi tinggi, paling berbahaya diantara sinar UV lainnya. Pada manusia pemaparan sinar UV yang berkepanjangan dapat menyebabkan kanker kulit, kerusakan mata dan menurunkan kekebalan tubuh. Terkait dengan kesehatan mata dampak dari pemaparan sinar UV yang berlebih dapat menyebabkan piterigum. World Health Organization (2010) menyatakan bahwa :

"Penyinaran ultraviolet pada mata yang berlebihan dapat menyebabkan fotokonjungtivitis, pterigium, katarak, kanker mata. Jika mata tidak terlindungi dan terkena radiasi sinar UV berlebihan dalam waktu singkat, bahkan hanya dalam beberapa jam saja akan menimbulkan efek fotokeratiti."
Maka dari itu perlu dilakukannya upaya untuk menghindari bahaya sinar UV terhadap kesehatan mata, salah satunya dengan menggunakan alat pelindung mata yaitu kacamata yang memiliki lapisan anti sinar UV, biasanya kacamata tersebut memiliki warnawarna gelap dan dilapisi anti sinar UV , sehingga paparan sinar UV akan di minimalisir masuk kedalam mata.

Terkait pemaparan diatas, dilakukan juga studi awal yang dilakukan di desa Cikaum Timur kabupaten Subang. Diambilnya tempat tersebut, dikarenakan sebagian besar warganya berpencaharian sebagai petani yang aktivitas sehari-harinya sering dilakukan diluar ruangan sehingga tidak menutup kemungkinan mendapat pancaran sinar UV dalam intensitas yang berlebih. Dari studi yang dilakukan didapatkan keterangan bahwa mereka pada umumnya bekerja diluar ruangan kurang lebih mencapai 10 jam. Terkait kesadaran tentang sinar UV, hamper $80 \%$ dari responden sama sekali tidak mengetahui sinar UV, sumber sinar UV dan cara melindunginya. Maka dari itu perlu dilakukan penanganan khusus guna mengantisipasi pancaran sinar UV yang berlebih salah satu dengan menggunakan alat pelindung mata dari pancran sinar UV. Disamping itu dperlukan juga tingkat kesadaran manusia akan pengetahuan mengenai sumber dan bahaya sinar UV terhadap kesehatan mata. 


\section{METODE PENELITIAN}

Penelitian bersifat deskriptif kuantitatif untuk mengetahui seberapa tahu petani tentang sinar UV terhadap kesehatan mata terutama mengetahui tentang bahaya sinar UV, Sumber Sinar UV dan alat pelindung mata dari sinar UV di desa Cikaum Timur kabupaten Subang.

Secara garis besar, kerangka konseptual penelitian dapat dilihat pada bagan dibawah ini.

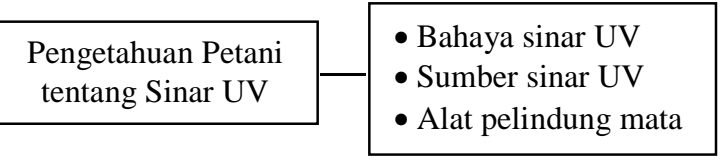

\section{Bagan 1 Kerangka Konsep Penelitian}

Populasi merupakan keseluruhan objek peneliti atau objek yang akan diteliti (Notoatmodjo, 2012). Dalam penelitian ini adalah semua petani di desa Cikaum Timur kabupaten Subang berjumlah 390 petani.

Sampel merupakan objek yang diteliti dan dianggap mewakili seluruh populasi. Karena adanya keterbatasan waktu, tenaga, biaya dan sebab lain (Notoatmodjo,2012). Dalam penelitian ini sampel yang diteliti adalah petani di desa Cikaum Timur kabupaten Subang pengambilan sampel dengan teknik Accidental Sampling, yaitu dilakukan dengan mengambil responden yang kebetulan ada di suatu tempat sesuai dengan konteks penelitian menjadi responden. Penentuan banyak sampel dengan perhitungan sampel penelitian Cross-sectional dengan rumus sebagai berikut menurut Lemeshowb dkk,1997:

$$
n=\frac{Z^{2-\alpha} / 2 p(1-p) N}{d^{2}(N-1)+\left(Z^{2} 1-\alpha / 2\right) p(p-1)}
$$

Keterangan :

$$
\begin{aligned}
& \mathrm{N}=\text { Besar Sampel } \\
& \mathrm{Z}^{2-\alpha / 2}=\text { Nilai } \mathrm{Z} \text { pada derajat kemaknaan } \\
& (90 \%=1,96)
\end{aligned}
$$

\section{Instrumen Penelitian}

Instrumen adalah alat ukur atau alat pengumpul data. Data yang diperoleh dari suatu pengukuran kemudian dianalisis dan dijadikan sebagai bukti dari suatu penelitian (Notoatmodjo,2012). Dalam penelitian ini instrumen penelitian yang digunakan yaitu kuesioner yang berisikan 15 pertanyaan yang terdiri dari 5 pertanyaan mengenai sumber sinar UV, 5 pertanyaan mengenai bahaya sinar UV dan 5 pertanyaan mengenai alat pelindung mata dari sinar UV. Sedangkan untuk mengetahui tingkat pengetahuan sinar UV di lihat dari 15 pertanyaan tersebut.

\section{Prosedur Pengambilan Data}

Pengambilan data yang dilakukan yaitu dengan membagikan kuisioner berisi daftar pertanyaan yang diajukan secara tertulis kepada sejumlah responden untuk mendapatkan tanggapan, informasi, jawaban dan sebagainya. Pada penelitian ini menggunakan sumber data primer yang langsung menanyakan kepada responden, dilakukan dengan cara: 
1. Peneliti mendatangi responden dengan cara door to door artinya mendatangi responden satu persatu dengan yang ada.

2. Peneliti membagikan surat persetujuan untuk menjadi responden dan meminta izin.

3. Setelah responden setuju, peneliti memberi penjelasan kepada responden mengenai penelitian dan memberikan lembaran kuesioner kepada responden.

4. Kuesioner penelitian berjumlah 15 pertanyaan responden cukup memberi tanda ceklis dengan kategori yang telah dibuat yaitu benar dan salah dan menunggu sampai kuesioner terisi penuh.

5. Setelah kuesioner terisi penuh peneliti langsung mengambilnya dan berpamitan untuk melanjutkan pengambilan data.

\section{Definisi Operasional Variabel Penelitian}

Variabel adalah sesuatu yang digunakan sebagai ciri, sifat, atau ukuran yang dimiliki atau di dapatkan oleh satuan penelitian tentang suatu konsep pengertian tertentu, misalnya umur,jenis kelamin, pendidikan, status pekawinan, pekerjaan, pengetahuan, pendapatan, penyakit, dan sebagainya (Notoatmodjo,2012). Variabel dalam peneliti ini menggunakan variabel independen yang meliputi: sumber sinar UV, bahaya sinar UV dan alat pelindung mata dari sinar UV. Sedangkan varibel terikatnya yaitu tingkat pengetahuan petani tentang sinar UV terhadap kesehatan mata.

\begin{tabular}{|c|c|c|c|c|}
\hline Variabel Terikat & \multicolumn{4}{|c|}{ Variabel Bebas } \\
\hline \multirow{4}{*}{$\begin{array}{l}\text { Pengetahuan } \\
\text { petani tentang } \\
\text { sinar UV }\end{array}$} & Sub Variabel & Definisi Operasional & Alat Ukur & Hasil UKur \\
\hline & Sumber sinar UV & $\begin{array}{l}\text { Benda yang dapat memancarkan sinar } \\
\text { UV }\end{array}$ & \multirow{3}{*}{ Kuisioner } & \multirow{3}{*}{$\begin{array}{l}\text { Kategori : } \\
\text { 1. Baik } \\
\text { 2. Cukup } \\
\text { 3. Kurang }\end{array}$} \\
\hline & Bahaya sinar UV & $\begin{array}{l}\text { Dapat merusak saraf pusat } \\
\text { penglihatan dan makula terutama } \\
\text { pada bagian kornea, lensa dan sclera }\end{array}$ & & \\
\hline & $\begin{array}{l}\text { Alat pelindung } \\
\text { mata dari sinar } \\
\text { UV }\end{array}$ & $\begin{array}{l}\text { Alat yang digunakan untuk } \\
\text { melindungi mata terhadap sinar UV }\end{array}$ & & \\
\hline
\end{tabular}

\section{ANALISIS DATA}

Analisa data adalah pengolahan data secara manual maupun menggunakan bantuan computer. Tujuan analisis ini adalah untuk menjelaskan atau mendeskripsikan masingmasing variabel baik variabel terkait atau variabel bebas. Untuk melakukan analisan dan secara univariat digunakan distribusi frekuensi (Arikunto,2013). Dalam penelitian ini analisa data menggunakan Analisis Univariat merupakan analisa yang digunakan untuk menjelaskan karakteristik masing-masing variabel yang akan diteliti. Dalam penelitian ini analisa univariat digunakan untuk menjelaskan atau mendeskripsikan angka atau

nilai karakteristik responden dan pengetahuan petani tentang sumber sinar UV, Bahaya sinar UV dan Alat pelindung mata dari sinar UV, dengan menggunakan distribusi frekuensi. sebagai berikut : 


$$
\mathrm{P}=\mathrm{F} / \mathrm{N} X 100 \%
$$

Keterangan :

$\mathrm{P}$ : Persentase yang dicari

F : Frekuensi responden untuk setiap pertanyaan

$\mathrm{N}$ : Jumlah responden

Dengan pengkategorian hasil analisis

Tabel hasil ukur (Arikunto ,2013)

\begin{tabular}{cc}
\hline Persentase (\%) & Kategori \\
\hline $76-100$ & Baik \\
\hline $56-75$ & Cukup \\
\hline$<56$ & Kurang \\
\hline
\end{tabular}

\section{HASIL DAN PEMBAHASAN}

\section{Hasil Penelitian}

Hasil Penelitian tentang tingkat pengetahuan petani tentang sinar UV terhadap kesehatan mata di desa Cikaum Timur kabupaten Subang disajikan dalam bentuk grafik sebagai berikut:

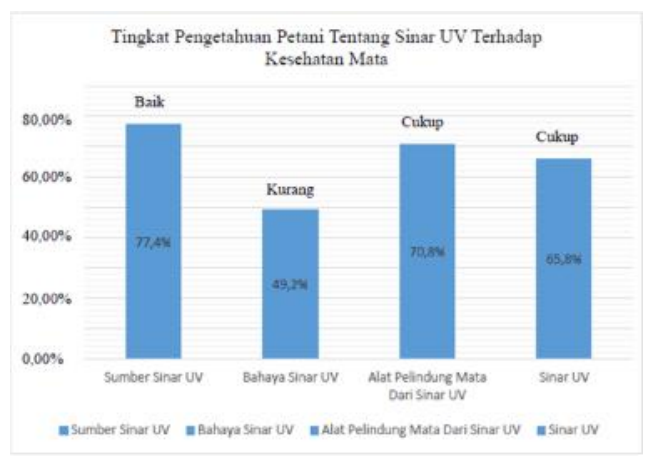

Berdasarkan grafik diatas dapat kita ketahui untuk tingkat pengetahuan sumber sinar UV dari lima pertanyaan yang disampaikan kepada responden menghasilkan total skor sebesar 302 sehingga tingkat pengetahuan responden tentang sumber sinar UV termasuk dalam kategori baik dengan nilai $(77,4 \%)$. Untuk tingkat pengetahuan bahaya sinar UV dari lima pertanyaan yang disampaikan kepada responden menghasilkan total skor 192 sehingga tingkat pengetahuan responden tentang bahaya sinar UV termasuk dalam kategori kurang dengan nilai $(49,2 \%)$. Untuk tingkat pengetahuan petani tentang alat pelindung mata dari sinar UV dari lima pertanyaan yang disampaikan kepada responden menghasilkan total skor 276 sehingga tingkat pengetahuan responden tentang alat pelindung mata dari sinar UV termasuk dalam kategori cukup dengan nilai (70,8\%). Untuk tingkat pengetahuan petani tentang sinar UV yang meliputi sumber, bahaya, dan alat pelindung mata dari sinar UV termasuk dalam kategori cukup dengan nilai $(65,8 \%)$.

\section{Pembahasan}

\section{Tingkat Pengetahuan Petani Tentang Sumber Sinar UV}

Berdasarkan grafik hasil penelitian yang telah dilakukan analisis univaria di atas dapat diketahui bahwa pengetahuan petani tentang sumber sinar UV di desa Cikaum Timur kabupaten Subang, termasuk dalam berpengetahuan baik $(77,4 \%)$. Sumber sinar UV diketahui berasal dari dua sumber yaitu alami dan buatan menurut WHO (2010) :

"Sumber sinar UV berasal dari dua sumber alami yaitu matahari dan buatan yang menghasilkan paparan sinar UV seperti laser, lampu fluorescent dan Light Emiting Diode (LED)"

Hal itu di sebabkan pengetahuan responden tentang sumber sinar UV masuk 
dalam kategori baik, karena responden selalu berinteraksi dengan sumber sinar UV alami maupun buatan, di samping itu responden juga memahami tentang kuesioner mengenai sumber sinar UV yang disampaikan oleh peneliti. Hasil penelitian ini sesuai dengan teori pengetahuan yang di sampaikan oleh Notoatmodjo,2012 menyatakan bahwa:

\begin{abstract}
"Pengetahuan adalah hasil tahu seseorang dan ini terjadi setelah pengindraan terjadi melalui panca indra penglihatan, pendengaran, penciuman, rasa dan raba sehingga sebagian besar pengetahuan manusia diperoleh melalui mata dan telinga".
\end{abstract}

\section{Tingkat Pengetahuan Petani Tentang Bahaya Sinar UV}

Berdasarkan hasil grafik menujukan bahwa didapatkan dari 78 responden tentang bahaya sinar UV di desa Cikaum Timur kabupaten subang termasuk dalam berpengetahuan kurang $(49,2 \%)$. Hal ini disebabkan karena ketidaktahuan responden terhadap bahaya sinar UV dan kurangnya informasi tentang bahaya sinar UV di dapatkan hasil berkategori pengetahuan kurang. Menurut hasil penelitian Christy Vera Widya Wideltha dengan judul tingkat pengetahuan keluarga tentang penyakit hipertensi di Jln Kalimantan RT02 dan 03 RW 17 kecamatan Pahandut Palangkaraya (2012) sebagai berikut:

"Faktor-faktor yang mempengaruhi tingkat pengetahuan adalah Umur, lingkungan, informasi, pendidikan dan minat. Informasi yang di peroleh dari pendidikan formal dan non formal dapat memberikan pengaruh jangka pendek sehingga menghasilkan perubahan atau peningkatan pengetahuan"

Bahaya sinar UV terhadap mata dapat menyebabkan kelainan patologi mata, seperti piterigium yang dialami oleh beberapa responden. Berdasarkan teori Alatas dan lusiyanti 2001, yang menyatakan hasil sebagai berikut:

“ bahaya sinar UV terhadap mata dapat merusak saraf pusat penglihatan dan macula, yaitu bagian dari retina yang terletak di bagian belakang mata. Sedangkan UV B dapat merusak bagian kornea dan lensa, paparan UV A dalam jangka panjang dapat mengakibatkan katarak. Penyakit lain yang ditimbulkan akibat sinar UV antara lain degenerasi macula, pterigium atau pertumbuhan selaput pada bagian seklera dan akhirnya menutupi bagian tengah kornea dan photokeratitis terjadi akibat paparan sinar UV B berlebihan"

Lamanya pemaparan menurut Horn (1999) menyatakan:

“ lama penyinaran akan berpengaruh terhadap aktivitas mahluk hidup misalnya pada manusia dan hewan. Juga akan berpengaruh pada metabolisme yang berlangsung pada mahluk hidup".

\section{Tingkat Pengetahuan Petani Tentang Alat Pelindung Mata Dari Sinar UV}

Berdasarkan hasil grafik menujukan bahwa dari 78 responden tentang pengetahuan alat pelindung mata dari sinar UV di desa Cikaum Timur kabupaten Subang termasuk dalam berpengetahuan cukup (70,8\%). Menurut (kamus besar bahasa Indonesia) alat non optik yang bisa melindungi mata dari paparan sinar matahari adalah sebagi berikut:

"caping atau topi berfungsi sebagai

penutup kepala dari terik matahari"

Hal ini sejalan dengan hasil observasi di lapangan bahwa sebagian responden sudah mengaplikasikan alat pelindung mata dari sinar UV ketika berkebun seperti menggunakan caping, topi dan menggunakan payung untuk 
menghindari dari paparan sinar UV, tetapi responden tidak menyadari akan hal itu ketika ditanyakan tentang alat pelindung mata dari sinar UV.

\section{Tingkat Pengetahuan Petani Tentang Sinar UV Terhadap Kesehatan Mata di desa Cikaum Timur kabupaten Subang tahun 2018}

Berdasarkan hasil grafik menujukan bahwa hasil rata-rata keseluruhan tingkat pengetahuan petani tentang sinar UV terhadap kesehatan mata di desa Cikaum Timur kabupaten Subang tahun 2018 termasuk dalam berpengetahuan cukup $(65,8 \%)$. Menurut Notoatmodjo (2012)

"Pengetahuan seseorang dipengaruhi oleh beberapa faktor diantaranya yaitu adalah suatu informasi yang diterima seseorang yang bisa di dapat melalui pegamatan yang dilakukan. Hal ini berkaitan dengan kemampuan berfikir, melihat, dan mendengar. Pengetahuan memiliki makna luas oleh karena itu perlu diseimbangkan pengetahuan yang bersifat nyata dimana kita sendiri yang menerapkan informasi yang di dapat"

Pengetahuan tentang sinar UV yang cukup berarti responden belum mampu sepenuhnya mengerti dan memahami tentang sinar UV. Menurut peneliti hasil penelitian menunjukan bahwa responden belum mampu sepenuhnya menganalisa setiap informasi yang diperoleh. Responden cukup baik dalam menjawab kuesioner walaupun belum sepenuhnya. Hal itu di sebabkan karena kurangnya informasi yang di dapat oleh responden dan kurangnya minat responden untuk mengetahui lebih jauh tentang apa itu bahaya sinar UV, alat pelindung mata dari sinar UV. Berpengetahuan cukup menurut Notoatmodjo (2012) bahwa:

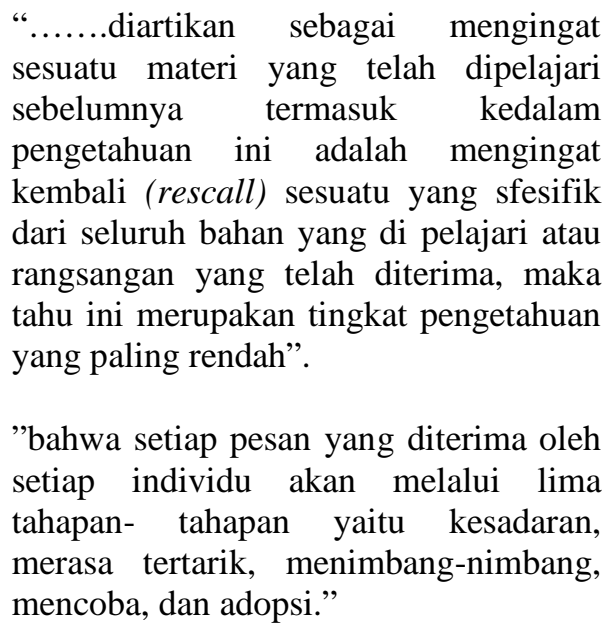

"bahwa setiap pesan yang diterima oleh setiap individu akan melalui lima tahapan- tahapan yaitu kesadaran, merasa tertarik, menimbang-nimbang, mencoba, dan adopsi."

Hal ini dikarenakan responden tidak berusaha untuk menambah pengetahuan tentang sinar UV terhadap kesehatan mata, kareana sebagian besar responden berpendidikan SD sehingga pengetahuan responden mengenai sinar UV sempit dan mengakibatkan kesadaran untuk menyimak informasi rendah dan tidak tertarik terhadap informasi tersebut.

\section{SIMPULAN DAN SARAN}

\section{Simpulan}

Berdasarkan hasil penelitian mengenai Tingkat Pengetahuan Petani Tentang Sinar UV Terhadap Kesehatan Mata Di desa Cikaum Timur kabupaten Subang tahun 2018 dapat di simpulkan sebagai berikut:

1. Tingkat pengetahuan petani tentang sumber sinar UV di desa Cikaum Timur kabupaten Subang mayoritas dalam kategori baik $(77,4 \%)$.

2. Tingkat pengetahuan petani tentang bahaya sinar UV di desa Cikaum Timur kabupaten Subang mayoritas dalam kategori kurang $(49,2 \%)$. 
3. Tingkat pengetahuan petani tentang alat pelindung mata dari sinar UV di desa Cikaum Timur kabupaten Subang mayoritas dalam kategori cukup (70,8\%).

4. Jadi tingkat pengetahuan petani tentang sinar UV terhadap kesehatan mata di desa Cikaum Timur kabupaten Subang Tahun 2018 yang meliputi sumber,bahaya dan alat pelindung mata dari sinar UV masuk dalam kategori berpengetahuan cukup $(65,8 \%)$.

\section{Saran}

Bagi penelitian berikutnya, disarankan dalam penyusunan instrument lebih memperhatikan aspek-aspek yang terdapat dalam masyarakat semisal instrument yang disusun mencakup faktor pendidikan, karena hal ini tidak menutup kemungkinan berpengaruh terhadap tingkat pengetahuan masyarakat.

Bagi masyarakat itu sendiri, diharapkan dapat mengikuti penyuluhan, konseling yang diberikan oleh tenaga kesehatan, sehingga mengetahui informasi tentang sinar UV yang sangat berguna pada kesehatan mata.

Dan bagi pihak pemerintah, diharapkan dapat memberikan pengetahuan yang lebih baik pada masyarakat dengan mengadakan penyuluhan kepada masyarakat tentang kesehatan mata.

\section{DAFTAR PUSTAKA}

Alatas \& Lusuyanti. 2001. Efek Kesehatan Radiasi Non Pegionan Pada Manusia SEMNAS. Pusat Penelitian Dan Pengembangan Keselamatan Radiasi Dan Biomedika Nuklir - BATAN: Jakarta

Amelia. 2010.Media Baru: From Noting To something, Dalam Potret Manajemen Media Di Indonesia. (Ed) Amir Effendi Siregar Dkk. Yogyakarta

American Optometric Association. 2008. people need sunglasses
Arikunto, S.2013. Prosedur Penelitian Suatu Pendekatan Praktik. Jakarta: PT. Rineka Cipta

Christy Vera Widya Wideltha. 2012. Tingkat pengetahuan keluarga tentang penyakit hipertensi di Jln Kalimantan RTO2 dan 03 RW $17 \quad$ kecamatan Pahandut Palangkaraya

Hidayat. A.A. 2014. Metode Penelitian Keperawatan dan Teknis Analisis. Jakarata: EGC

Horn. 1999. Tentang Penyinaran Metabolisme Dan Berlangsung Pada Tubuh Mahluk Hidup Intan 2013. Tentang Gangguan Kesehatan Kronik Pada Kulit, Mata, Otak Sistem Imun Dan Organ. EGC. Jakarta

Isfardiyana, S. H. 2014. Pentingnya Melindungi Kulit Dari Sinar Ultraviolet Dan Cara Melindungi Kulit Dengan Sunblock Buatan Sendiri. Asian Journal Of Innovation And Enterpreneurship, 3(2), 126-133.

Komalasari, Rossa. 2015. Pengaruh Independensi, Kompleksitas Tugas, dan Gender Terhadap Audit Judgment, SNA X, 26-18 Juli 2007, Makasar

Lemeshow,S.\& David W.H.Jr. 1997. Besar Sampel Dalam Penelitian Kesehatan (terjemahan), Gadjahmada University Press, Yogyakarta

Notoatmodjo.2012. Metodologi Penelitian Kesehatan. Jakarta. Rineka Cipta.

Priyanto, P., \& Tarwaka, P. 2016. Hubungan Tingkat Kedisiplinan Pemakaian Alat Pelindung Mata Dengan Gangguan Kesehatan Mata Pada Pekerja Las Home Industry Di Kartasura (Doctoral Dissertation, Universitas Muhamadiyah Surakarta).

Riskesdas.2013 . Kesehatan Indra Prevalensi Pterygium,Kekeruhan Kornea, Dan Katarak, Secara Nasional

Rodjak, Abdul. 2006. Manajemen Usaha Tani. Jilid II. Bandung: Pustaka Gratuna

Sidarta Ilys. 2014. Ilmu Penyakit Mata Edisi Kelima. Jakarta: FKUI

WHO, World Health Organization.2010. The Know Health Effects of UV

Wiliam J. Benjamin Irvin M Borish. 1998. Clinical Refraction. USA : Saunders Company. 